\title{
Correction to: Operationalizing salesperson performance with secondary data: aligning practice, scholarship, and theory
}

Willy Bolander $^{1}$ (D) Nawar N. Chaker ${ }^{2} \cdot$ Alec Pappas $^{1} \cdot$ Daniel R. Bradbury $^{1}$

Published online: 22 May 2021

(C) Academy of Marketing Science 2021

Correction to: Journal of the Academy of Marketing Science (2021) 49:462-481 https://doi.org/10.1007/s11747-020-00752-0

Table 1 in the original version of this article contained typographical errors. The correct data is shown below:

The online version of the original article can be found at https://doi.org/ 10.1007/s11747-020-00752-0

Willy Bolander

wbolander@business.fsu.edu

Nawar N. Chaker

nawarchaker1@1su.edu

Alec Pappas

apappas@fsu.edu

Daniel R. Bradbury

db13m@my.fsu.edu

1 College of Business, Florida State University, 821 Academic Way, Tallahassee, FL 32306-1110, USA

2 E.J. Ourso College of Business, Louisiana State University, 501 South Quad Drive, Baton Rouge, LA 70803, USA 
Table 1 Pros and cons of primary vs. secondary salesperson performance data

\begin{tabular}{|c|c|c|c|c|}
\hline & \multicolumn{2}{|l|}{ Primary Data } & \multicolumn{2}{|l|}{ Secondary Data } \\
\hline & Pros & Cons & Pros & Cons \\
\hline $\begin{array}{l}\text { Conceptual } \\
\text { Considerations }\end{array}$ & $\begin{array}{l}\text { - Ability to capture } \\
\text { unobservable aspects of } \\
\text { performance } \\
\text { (e.g., cognitive and } \\
\text { emotional) } \\
\text { - Ability to capture } \\
\text { perspectives of varying } \\
\text { groups } \\
\text { (salesperson, manager, } \\
\text { customer) }\end{array}$ & $\begin{array}{l}\text { - Individual interpretation of } \\
\text { survey items may differ by } \\
\text { respondent } \\
\text { - Questionable face validity that } \\
\text { may not always align with } \\
\text { practitioners' perspectives }\end{array}$ & $\begin{array}{l}\text { - Clear face validity that aligns } \\
\text { with practitioners' } \\
\text { perspectives } \\
\text { - Less susceptible to invariance } \\
\text { due to self-reporting bias }\end{array}$ & $\begin{array}{l}\text { - Limited in scope to data that is } \\
\text { observable and easily } \\
\text { recorded } \\
\text { - Restricted to examining only } \\
\text { variables that are deemed } \\
\text { important by the company }\end{array}$ \\
\hline $\begin{array}{l}\text { Logistical } \\
\quad \text { Considerations }\end{array}$ & $\begin{array}{l}\text { - Simple to collect from, } \\
\text { and compare across, } \\
\text { different organizations } \\
\text { and industries } \\
\text { - Ease in maintaining } \\
\text { anonymity because no } \\
\text { connections need to be } \\
\text { made with company } \\
\text { records }\end{array}$ & $\begin{array}{l}\text { - More time and resource } \\
\text { intensive to collect } \\
\text { - Reduced flexibility with data } \\
\text { gathering for time-lagged var- } \\
\text { iables or repeated measures for } \\
\text { longitudinal research }\end{array}$ & $\begin{array}{l}\text { - Data is extant which has a } \\
\text { negligible impact on } \\
\text { employee, firm, or } \\
\text { researcher time to collect } \\
\text { - Variety of performance } \\
\text { variables available for } \\
\text { appropriate DV selection } \\
\text { and potential robustness } \\
\text { checks }\end{array}$ & $\begin{array}{l}\text { - Difficulty in maintaining } \\
\text { anonymity as data matching } \\
\text { (i.e., survey data to secondary } \\
\text { data) is required } \\
\text { - Requires disclosure of private } \\
\text { performance data, which may } \\
\text { involve approval from legal } \\
\text { department or HR }\end{array}$ \\
\hline $\begin{array}{l}\text { Methodological } \\
\text { Considerations }\end{array}$ & $\begin{array}{l}\text { - Measurement scales } \\
\text { readily available and } \\
\text { established } \\
\text { (e.g., Behrman \& } \\
\text { Perreault 1982) } \\
\text { - Allows the researcher to } \\
\text { control for measurement } \\
\text { error via multi-item scales }\end{array}$ & $\begin{array}{l}\text { - Higher participant response } \\
\text { rates are a challenge, } \\
\text { especially in B2B sales } \\
\text { - Susceptible to common method } \\
\text { bias, } \\
\text { rater biases, survey fatigue, } \\
\text { etc. }\end{array}$ & $\begin{array}{l}\text { - Ease in gathering data from } \\
\text { multiple time points to track } \\
\text { growth trends } \\
\text { - Ability to gather data on a } \\
\text { larger percentage of a firm's } \\
\text { salespeople }\end{array}$ & $\begin{array}{l}\text { - Additional time and effort } \\
\text { required to purify the data and } \\
\text { ensure data integrity } \\
\text { - Dependent on company's } \\
\text { organization, reliability, and } \\
\text { presentation of the data }\end{array}$ \\
\hline
\end{tabular}

Publisher's note Springer Nature remains neutral with regard to jurisdictional claims in published maps and institutional affiliations. 